\title{
A review and report of peripheral giant cell granuloma in 8-year-old child with infective endocarditis
}

\begin{abstract}
This is a case report of a patient with a 6-month history of a slowly growing, asymptomatic nodular mass in the anterior maxillary region with non erupting permanent teeth. The medical history shows that she is a known infective endocardititis patient. Surgical excision of the lesion was done under antibiotic prophylaxis. The biopsy report was conclusive of peripheral giant cell granuloma.
\end{abstract}

Keywords: infective endocarditis, unerupted permanent teeth, peripheral giant cell granuloma
Volume 5 Issue 3 - 2018

\author{
Nagendran jayavel pandiyan,' Dhanu G Rao, ${ }^{2}$ \\ Latha Anandakrishna, ${ }^{3}$ Prakashchandra, ${ }^{3}$ \\ Dhananjaya $\mathrm{G}^{3}$ \\ 'Department of Paediatric Dentistry, Penang international dental \\ college, Malaysia \\ ${ }^{2}$ Department of Pedodontic and Preventive Dentistry, AMES \\ Dental College, India \\ ${ }^{3}$ Department of Pedodontics and Preventive Dentistry, MS \\ Ramaiah Dental College, India
}

Correspondence: Nagendran jayavel pandiyan, Department of Paediatric Dentistry, Penang international dental college, Penang, Malaysia- 12000,Tel 0060124959675 , Email nagaped@gmail.com

Received: February 24, 2018 | Published: May 21, 2018

\section{Introduction}

Peripheral giant cell granuloma (PGCG) is the most common giant cell lesion of the jaws. ${ }^{1}$ The condition has also been referred to as peripheral giant cell tumor, giant cell epulis, osteoclastoma, reparatory giant cell granuloma, and giant cell hyperplasia of the oral mucosa. ${ }^{2}$

PGCG is a well-circumscribed lesion confined to the alveolar and gingival mucosa, originating from the connective tissue of the periosteum or the periodontal ligament. ${ }^{1,3}$ It may present as a firm or soft nodule and as a sessile or a pedunculated mass. The color of the lesion ranges from dark red to purple, maroon, or blue, and the surface may occasionally be ulcerated. ${ }^{1,4,5}$

The lesion is characterized histologically by multinucleated giant cells with a background of ovoid to spindle-shaped mesenchymal cells. ${ }^{6}$ The lesion can develop at any age, although it is more common between the fifth and sixth decades of life, with a slight predilection for females ${ }^{7}$ and they rarely exceed $2 \mathrm{cms}$ in diameter. ${ }^{8}$

It is not considered as true neoplasm; rather it is thought to be a reactive lesion or a tumor-like growth caused by local irritation or trauma. ${ }^{4}$ The local causative factors associated with PGCG, includes complicated dental extractions, dental restorations in poor condition, food impaction, dental malposition, plaque, and calculus. ${ }^{3,9,10}$

\section{Case report}

An 8 year old patient was reported to the Department of Pedodontics, M.S Ramaiah Dental College and Hospital, Karnataka, India with a complaint of non erupting teeth in upper anterior region .The patient complained of slowly enlarging exophytic mass over a 3-month period in the maxillary anterior region . The patient had general discomfort in the area but denied any altered sensation.
The lesion was noted to bleed easily on brushing the tooth and by impinging of lower central incisors.

The patient is a known case of infective endocarditis and she was under medications previously, but she stopped medication from the past 1 year. The intraoral examination revealed a $2.0 \times 1.5 \mathrm{~cm}$ lesion with a non ulcerated smooth-surfaced, reddish colored nodule involving the attached gingiva in anterior maxillary region with missing permanent central incisor (Figure 1) (Figure 2). The lesion did not extend into the vestibular mucosa. The lesion showed no signs of regression. An intra oral periapical and occlusal radiographs were taken which revealed no bony involvement and the permanent central incisors were blocked. ${ }^{11}$

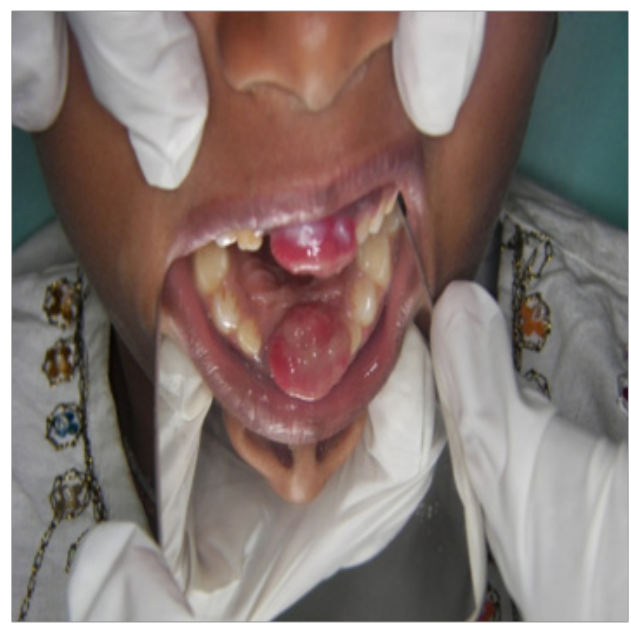

Figure I Intraoral view. 
The patient was referred for cardiologist opinion. The antibiotic prophylaxis was done by, using Ampicillin $50 \mathrm{mg} / \mathrm{kg}$ and Gentamicin $2 \mathrm{mg} / \mathrm{kg}$ was given intravenously 30 minutes before the procedure as recommended by cardiologist. The lesion was excised completely under local anesthesia and the upper permanent centrals were exposed. The histological evaluation of biopsy showed the presence of numerous giant cells in a well-vascularized connective tissue stroma of ovoid and spindle-shaped mesenchymal cells (Figure 3). The lesion was identified as a peripheral giant cell granuloma. There were no complications in the immediate postoperative period (Figure 4). At successive follow-up visits over the next 6 months, there were no evidence of recurrence.

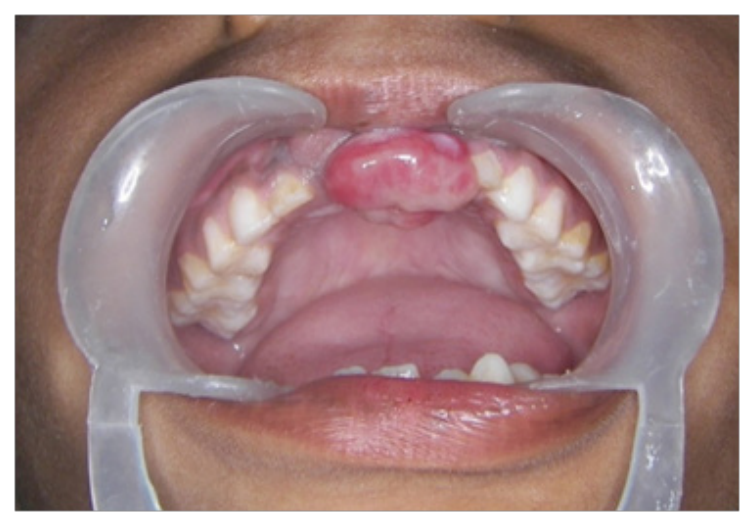

Figure 2 Intraoral view.

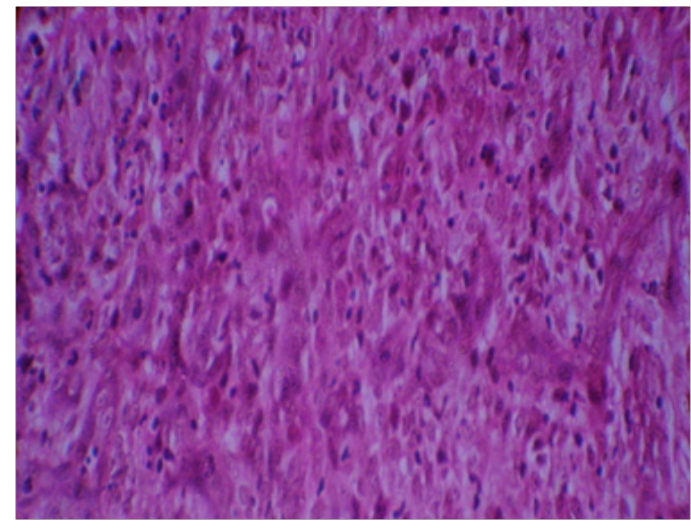

Figure 3 Histopathology of specimen.

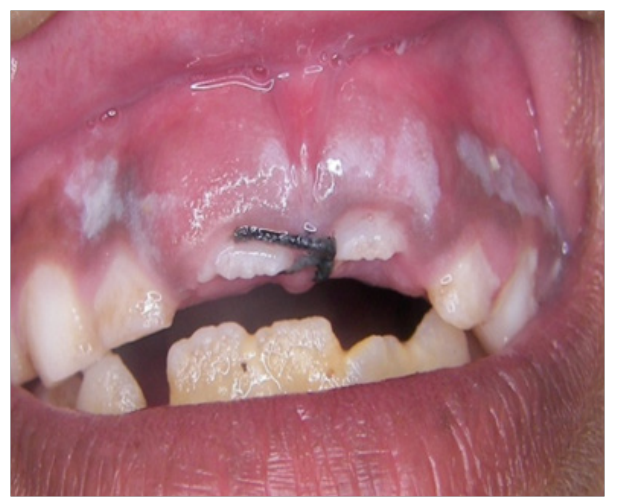

Figure 4 Postoperative after I week.

\section{Discussion}

PGCGs have rarely been reported to develop in association with erupting teeth. The clinical appearance of PGCG is a small, welldemarcated, dark red focal mass on the gingiva with a sessile or pedunculated base usually originating from either the periodontal ligament or mucoperiosteum..$^{2,4,12}$

The high frequency of reactive focal overgrowth in the gingiva is likely to be a result of the irritational factors in the oral cavity in conjunction with the unique anatomy of the gingival attachment. The PGCG is unique to the gingival mucosa. There are no reported cases occurring in extra gingival sites. ${ }^{4,12}$ This may be related to the anatomic nature of the gingiva and the irritational factors at this site. ${ }^{13,14}$

In children, PGCG similar to other reactive oral lesions appears to have a rapid growth rate, be more aggressive with infiltration of the interproximal crest area and bone resorption, interfere with eruption of adjacent teeth, produce minor to moderate tooth movement, and have multiple recurrences. ${ }^{11}$ Therefore considering the probability of PGCG in gingival enlargements even in the children under 5 years old reduces its consequences and prevents clinicians' misdiagnosis as in the case that lead to unreasonable extraction of primary incisors. ${ }^{15}$ PGCG can be easily distinguished from parulis, which is frequently associated with a necrotic tooth or with periodontal disorder. Radiographs are essential for confirming the oral mucosa origin of the giant cell lesion and refusing a central bony lesion with cortical perforation and soft tissue extension. Early detection of the PGCG results in more conservative surgery with less risk for tooth and bone loss. ${ }^{1}$

Solitary gingival enlargements in children are relatively common and usually occur in reaction to local irritation or chronic trauma. One of these enlargements is peripheral giant cell granuloma (PGCG), a lesion unique to the oral cavity, occurring only on the gingiva. It is distinguishable from similar lesion only on the basis of its unique histomorphology, which is essentially identical to that of central giant cell granuloma, intrabony benign neoplasm of the jawbone. ${ }^{16}$

In differential diagnosis in the cases of gingival enlargements in children we consider four main lesions: pyogenic granuloma, peripheral giant cell granuloma, peripheral ossifying fibroma, and peripheral odontogenic fibroma. Peripheral giant cell granuloma, like the peripheral ossifying fibroma, is a lesion unique to the oral cavity, occurring only on the gingiva. Unlike peripheral ossifying fibroma, however, it may occur on the alveolar mucosa of edentulous areas. Like pyogenic granuloma and peripheral ossifying fibroma, peripheral giant cell granuloma may represent an unusual response to tissue injury. It is distinguishable from pyogenic granuloma and peripheral ossifying fibroma only on the basis of its unique histomorphology, which is the same as central giant cell granuloma. ${ }^{17,18}$ Clinically, peripheral odontogenic fibroma (WHO type) must be considered in the differential diagnosis of dome-shaped or nodular, nonulcerated, growths on the gingiva like PGCG. Peripheral odontogenic fibroma is characterized by a fibrous or fibromyxomatous stroma containing varying numbers of islands and strands of odontogenic epithelium that is clearly distinguishable from PGCG histopathology..$^{19}$ Pain is not a common characteristic, and lesion growth in most cases is induced by repeated trauma. ${ }^{16}$

The microscopic appearance of PGCG is unique mainly because of the large number of multinucleated giant cells dispersed in the 
connective tissue stroma. The precise origin of the giant cells has never been established. Different views have been proposed by a number of authors based on light and electron microscopic studies, and the possible sources may be osteoblasts, phagocytes, endothelial cells, and spindle cells. ${ }^{12,14,20,21}$

In the most recent study by Bo Liu et al. ${ }^{22}$ in situ hybridization was carried out to detect the mRNA expression of the newly identified receptor activator of nuclear factor (NF)-kappaB ligand (RANKL) that is shown to be essential in the osteoclastogenesis, its receptor, receptor activator of NF-kappaB (RANK), and its decoy receptor, osteoprotegerin (OPG). They concluded that RANKL, OPG and RANK expressed in these lesions may play important roles in the formation of multinucleated giant cells.

Furthermore, the recently identified membrane-bound protein family, a disintegrin and metalloprotease (ADAM), is considered to play a role in the multinucleation of osteoclasts and macrophagederived giant cells from mononuclear precursor cells. ${ }^{23}$

The treatment of PGCG comprises surgical resection and elimination of the underlying etiologic factors ${ }^{1,4}$ with complete removal of the entire base of the lesion. If the resection of the lesion is too superficial or incomplete then the lesion may recur. ${ }^{1}$ The recurrence of the lesion is infrequent and is observed in 5\% to $11 \%$ of cases according to Eversole and Rovin ${ }^{10}$ and Mighell et al. ${ }^{11}$ respectively.

Although infective endocarditis (IE) is a rare condition in the population in general, it continues to be a serious complication, mainly in patients who possess susceptible cardiac conditions. ${ }^{24}$ The relationship between oral microorganisms and the development of infective endocarditis is well known. The causative microorganisms for infective endocarditis in more than $60 \%$ of the patients with positive haemoculture are streptococci, ${ }^{25}$ with viridians streptococci representing $50 \%$ of this group, especially Streptococcus sanguis, S. mitior and S. mutans. ${ }^{26}$ The British Society of Antimicrobial Chemotherapy considered that despite the lack of evidence of the benefit for antibiotic prophylaxis to prevent IE associated with dental procedures, many clinicians would be reluctant to accept the radical, but logical, step of withholding antibiotic prophylaxis for dental procedures (Gould et al. 2006). Even though controversies exist in usage of antibiotic prophylaxis, we performed the procedure after prophylaxis as the benefits outweighed the side effect due to antibiotics. This case shows PGCG lesion after complete surgical excision with no signs of recurrence. In conclusion, Early diagnosis based on clinical and radiological findings and confirmed by pathological analysis with conservative management will help to reduce esthetic and functional defect in the adjacent teeth and tissues of the young pediatric patients.

\section{Acknowledgements}

None.

\section{Conflict of interest}

The author declares that there is no conflict of interest.

\section{References}

1. Flaitz CM. Peripheral giant cell granuloma: a potentially aggressive lesion in children. Pediatr Dent. 2000;22(3):232-223.

2. Kfir Y, Buchner A, Hansen L. Reactive lesions of the gingiva. A clinico pathological study of 741 cases. J Periodontol. 1980;51:655-661.

3. Pandolfi PJ, Felefli S, Flaitz CM, Johnson JV. An aggressive peripheral giant cell granuloma in a child. J Clin Pediatr Dent. 1999;23(4):353-355.

4. Katsikeris N, Kakarantza-Angelopoulou E, Angelopoulous AP. Peripheral giant cell granuloma: clinico- pathologic study of 224 new cases and 956 reported cases. Int J Oral Maxillofac Surg. 1988;17(2):94-99.

5. Bodner L, Peist M, Gatot A, et al. Growth potential of a peripheral giant cell granuloma. Oral Surg Oral Med Oral Pathol Oral Radiol Endod. 1997;83(5):548-551.

6. de Souza PE, Paim JF, Carvalahais JN, et al. Immunohistochemical expression of p53, MDM2, Ki-67 and PCNA in a central giant cell granuloma and giant cell tumor. J Oral Pathol Med. 1999;28:54-58.

7. Chaparro-Avendano AV, Berini-Ayetes L, Gay-Escoda C. Peripheral giant cell granuloma. A report of five cases and review of the literature. Med Oral Pathol Oral Cir Bucal. 2005;10(1):48-57.

8. Gándara-Rey JM, Pacheco Martins Carneiro JL, Gandara-Vila P, et al. Peripheral giant-cell granuloma. Review of 13 cases. Med Oral. 2002;7(4):254-259.

9. Bhaskar SN, Cutright DE, Beasley JD, et al. Giant cell reparative granuloma (peripheral): report of 50 cases. J Oral Surg. 1971;29(2):110-115.

10. Eversole LR, Rovin S. Reactive lesions of the gingiva. J Oral Pathol. 1972;1(1):30-38.

11. Mighell AJ, Robinson PA, Hume WJ. Peripheral giant cell granuloma: a clinical study of 77 cases from 62 patients and literature review. Oral Dis. 1995;1(1):12-19.

12. Shafer WG, Hine MK, Levy BM. A textbook of oral pathol. 4th ed. Philadelphia: WB Saunders; 1983:144-146.

13. Dayan D, Buchner A, Spirer S. Bone formation in peripheral giant cel granuloma. J Periodontol. 1990;61:444-446.

14. Lucas RB. Pathology of tumors of the oral tissues. 4th ed. London: Churchill Livingstone, 1984:259-72.

15. Afsaneh Nekouei, Alireza Eshghi, Parisa Jafarnejadi, et al. A Review and Report of Peripheral Giant Cell Granuloma in a 4-Year-Old Child. Case Reports in Dentistry. 2016:1-4.

16. BW Neville, DD Damm, CM Allen, et al. "Soft tissue tumors, " in Oral and Maxillofacial Pathology. BW Neville, DD Damm, et al. editors. Philadelphia: WB Saunders; 2015: 485.

17. Andersen L, Fejerskov O, Philipsen HP. Oral giant cell granulomas. A clinical and histological study of 129 new cases. Acta Pathologica et Microbiologica Scandinavica A. 81(5):606-616.

18. Giansanti JS, Waldron CA. Peripheral giant cell granuloma: review of 720 cases. J Oral Surg. 27(10):787-791.

19. Daley TD, Wysocki GP. Peripheral odontogenic fibroma. Oral Surgery Oral Medicine Oral Pathology Oral Radiology. 1994;78(3):329-336.

20. Bodner L, Dayan D. Growth potential of peripheral ossifying fibroma. $J$ Clin Periodontol. 1987;14(9):551-554. 
21. Flanagan AM, Tinkler SMB, Horton MA, et al. The multinucleate cells in giant cell granulomas of the jaws are osteoclasts. Cancer. 1988;62(6):11391145 .

22. Bo Liu, Shi Feng Yu, Tie-Jun Li. Multinucleated giant cells in various forms of giant cell containing lesions of the jaws express features of osteoclasts. J Oral Pathol Med. 2003;32(6):367-375.

23. Abe E, Mocharla H, Yamate T, et al. Monolages SC. Meltrinalpha, a fusion protein involved in multinucleated giant cell and osteoclast formation. Calcif Tissue. 1999;64(6):508-515.
24. Cowper TR. Pharmacologic management of the patient with disorders of the cardiovascular system. Dental Clinics of North America. 1996;40:611-647.

25. Bayliss R, Clarke C, Oakley C, et al. The microbiology and pathogenesis of infective endocarditis. British Heart Journal. 1983;50:513-519.

26. Knox KW, Hunter N. The role of oral bacteria in the pathogenesis of infective endocarditis. Aust Dent J. 1991;36(4):286-292. 